\title{
Alveolar Ridge Conservation by Early Bone Formation After Tooth Extraction in Rabbits. A Histomorphological Study
}

\author{
Conservación de la Cresta Alveolar por Formación Ósea Temprana después \\ de la Extracción Dentaria en Conejos. Un Estudio Histomorfológico
}

Mario Cantín",**; Sergio Olate ${ }^{*, * * *}$; Ramón Fuentes* \& Bélgica Vásquez*****

CANTIN, M.; OLATE, S.; FUENTES, R. \& VÁSQUEZ, B. Alveolar ridge conservation by early bone formation after tooth extraction in rabbits. A histomorphomological study. Int. J. Morphol., 33(1):369-374, 2015.

SUMMARY: Alveolar ridge volume loss is an irreversible process. To prevent this physiological event, which typically result in significant local anatomical changes in both the horizontal and the vertical dimension, some strategies are indicated to minimize the loss of ridge volume that typically follows tooth extraction. The purpose of this study was to evaluate if three different bone grafts could promote new bone formation in the alveolar socket following tooth extraction for the alveolar ridge conservation. First mandibular molars of male adults rabbits were extracted and the extraction sockets were randomly treated with three different bone grafts, one xenograft and two alloplastic grafts, and a group that received no treatment (blood clot). The extraction sockets of selected rabbits from each group were evaluated at 4, 6, or 8-week post-extraction. The results indicated that the extraction sockets treated with alloplastic graft (biphasic calcium phosphate) exhibited lamellar bone formation $(6.5 \%)$ as early as four weeks after the extraction was performed. Moreover, the degree of new bone formation was significantly higher $(\mathrm{P}<0.05)$ in the extraction sockets treated with biphasic calcium phosphate at 8-week post-extraction than that in the other study groups. In this study, we demonstrated that the proposed animal model is useful to evaluate the bone formation after tooth extraction and the alveolar ridge conservation is feasible. The new bone formation and alveolar ridge preservation with bone graft after extraction of molar teeth, could result in the maintenance of sufficient bone volume to place an implant in an ideal restorative position without the need for ancillary implant site development procedures.

KEY WORDS: Tooth Socket; Bone grafting; Alveolar bone loss; Alveolar ridges preservation.

\section{INTRODUCTION}

Dental extraction is indicated when a tooth cannot be restored or maintained in acceptable conditions for longterm health, function, or esthetics. Tooth loss has a direct impact on quality of life by impairing the ability to masticate, speak, and, in some instances, socialize (Gerritsen et al., 2010).

Additionally, the absence of a tooth in its alveolus triggers a cascade of biological events that typically result in significant local anatomic changes (Van der Weijden et al., 2009). Preclinical and clinical studies have demonstrated that the alveolar ridge volume loss post extraction is an irreversible process, that involves both horizontal and vertical reduction (Schropp et al., 2003; Araújo \& Lindhe, 2009). Alveolar ridge atrophy may have a considerable impact on tooth replacement therapy, particularly when implantsupported restorations are planned (Seibert \& Salama, 1996). Therefore, alveolar ridge preservation has become a key component of actual clinical dentistry.

The natural healing process usually occurs with reduction of the height and width of the alveolar bone. To prevent this, alveolar ridge preservation via socket grafting emerged as a therapeutic alternative to root submergence. Its use was rationalized on the notion that filling the space left by the extracted tooth with a biomaterial would emulate a root retention effect, conducive to bone preservation, which would subsequently facilitate dental implant placement by reducing the need for ancillary grafting procedures (Artzi \& Nemcovsky, 1998).

Departamento de Odontología Integral, Facultad de Odontología Universidad de La Frontera, Temuco, Chile.

** Programa de Doctorado en Ciencias Morfológica, Facultad de Medicina, Universidad de La Frontera, Temuco, Chile.

*** Centro de Investigación en Ciencias Biomédicas, Universidad Autónoma de Chile, Temuco, Chile.

***** Universidad de Tarapacá, Arica, Chile.

This project has been funded by Universidad de La Frontera, DI13-0064. 
Over the past two decades, multiple studies evaluating the efficacy of different socket-filling approaches have been conducted. In these studies, a variety of biomaterials has been employed, including autologous bone, bone substitutes (allografts, xenografts, and alloplastic), autologous bloodderived products, and bioactive agents, among others (Darby et al., 2009). This body of knowledge contains a wealth of clinical, radiographic, and histologic outcomes.

The aim of this study was to evaluate if three different bone grafts could promote new bone formation in the alveolar socket following tooth extraction for the alveolar ridge conservation.

\section{MATERIAL AND METHOD}

Ethics statement. The animal experiments performed in this study were approved by the Institutional Ethic Committee at the Universidad de La Frontera, Protocol Nº19/13.

Experimental design. Three bone substitutes were used, as follows: one xenograft consisting of deproteinized and lyophilized bovine bone - Bio-Oss, and two fully alloplastic one based on pure phase beta-tricalcium phosphate (TCP) (>99\%) (alloplastic graft 1) and other based on biphasic calcium phosphate (60\% HA / 40\% beta-TCP) (alloplastic graft 2). In one group (control), extraction socket was filled with a blood clot.

Graft implantation. Pre and postoperatively, the animals were kept in individual cages in a temperature-controlled environment with water ad libitum and standardized feed (only preoperatively and five days postoperatively). The animals were anesthetized intramuscularly using $0.1 \mathrm{ml} /$ $200 \mathrm{~g}$ of animal weight, using equal parts of ketamine and xylazine. A buccal mucoperiosteal flap was raised with a periosteal elevator to expose the extraction socket of first mandibular molar tooth. Bilateral extraction of the first mandibular molars of sixteen male rabbits was performed (Manso et al., 2011), divided at random into four groups $(\mathrm{n}=4$ in each group). Immediately after removing the teeth, in group 1 (control, no graft treatment), the extraction sockets (left and right) were left empty, to be filled with blood clot (Fig. 1A). In groups 2, 3 and 4, the extraction sockets (left and right) were treated with xenograft (Fig. 1B), alloplastic graft 1 and alloplastic graft 2, respectively. The flap was sutured with 4-0 polyglyconate in a simple, interrupted pattern.

Oral alimentation was reinitiated 24 hours after surgery with soft food, which was offered during five days.
After this period, the animals were fed with commercial rabbit diet. Rabbits were sacrificed at 4, 6, or 8 wk postextraction for the analysis of the extraction sites.

Histological Assessment.. Block sections of the mandibles that contained the extraction wounds were removed and subsequently fixed in $10 \%$ formalin. After fixation, the tissues were fixed further in $10 \%$ neutral buffered formalin, decalcified in $5 \%$ formic acid, embedded in paraffin, sectioned at five $\mathrm{mm}$ increments, and stained with hematoxylin and eosin. All of the sections were evaluated using a Olympus ${ }^{\circledR}$ CX 31 microscope with a Moticam ${ }^{\circledR} 480$ camera, for the presence or absence of grafts and bone regeneration.

One section from each socket was selected for further analysis based on the largest area of degree of bone mineralization or the greatest amount of bone regeneration observed. Graft tissues were examined histologically for evidence of osteoinduction using a qualitative scoring method, described by Boyan et al. (2006). In addition, histomorphometry was used to assess the amount of new bone formation, the size of individual ossicles, the area of each ossicle occupied by marrow, and the amount of residual graft material.

The qualitative scoring were categorized as follows:

- Sections exhibiting no evidence of the degree of bone mineralization or new bone growth were scored as 0 .

- Sections in which degree of bone mineralization was observed, but no new bone or cartilage was present, were assigned a score of 1 .

- Sections in which a single ossicle (marrow space surrounded by new bone and degree of bone mineralization) was observed were assigned a score of 2 .

Sections in which 2 or more ossicles were present were assigned a score of 3 .

- Sections containing highly osteoinductive grafts, for which $70 \%$ of the slide at 10x magnification was covered with an ossicle, were assigned a score of 4 .

Statistical analysis. The results of the analysis of both the continuous and categorical variables are presented as the mean and standard deviation (Mean \pm SD). Differences in the measured properties between the study groups were evaluated using a one-way analysis of variance with $95 \%$ confidence intervals. Differences with a $\mathrm{P}$ value less than 0.05 were considered statistically significant. 


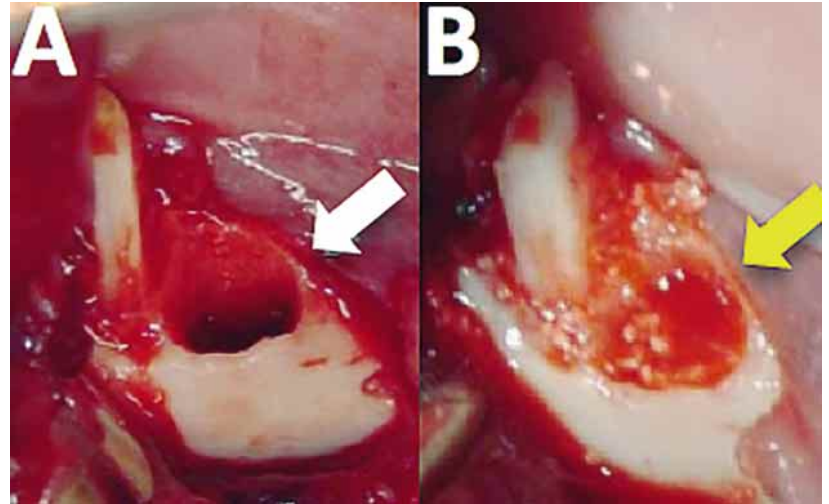

Fig. 1. A, show the tooth socket of the first mandibular molar and B, extraction socket filled with xenograft consisting of deproteinized and lyophilized bovine bone.

\section{RESULTS}

The results of the histopathological assessment are shown in Fig. 2. At four-week post-extraction, the sections exhibited significantly more new bone formation in the sockets treated with alloplastic graft two than in the other study groups. After $6 \mathrm{wk}$ of healing, at least 2 or more sites of new bone or ossicle formation were visible in the sockets treated with alloplastic graft 1 or alloplastic graft 2 , whereas significantly less bone formation was observed in the sockets treated with the xenograft and in the control sockets. At 4, 6 , and 8 weeks post-extraction, the sockets treated with alloplastic graft 2 received the highest qualitative scores for bone formation $(\mathrm{P}<0.05)$, followed by those treated with the alloplastic graft 1 , the control extraction sockets, and xenograft, in the order of decreasing scores.
Histomorphometric data of the present study show no significant statistical differences in the heights of the buccal and lingual plates when comparing the experimental group with controls. In the control Group, at four-week postextraction, sockets were filled with granulation or connective tissues, and displayed prominent inflammatory cell infiltration consisting mainly of granulocytes, whereas no new bone was visible in the socket. At six-week postextraction, a small amount of trabecular bone formation was visible along the walls of the control group sockets. However, the central region of the sockets remained filled with connective tissues, and no significant inflammatory cell infiltration was observed. At eight week post-extraction, a significant amount of newly formed bone was present between the periphery and the central region of the control alveolar sockets.

In the xenograft Group, the extraction sockets treated at 4 and 6 weeks exhibited characteristics that were similar to those of the control group. At 8 weeks, a small amount of trabecular bone formation occurred in the central region, and additional trabecular bone formation occurred in the peripheral regions of the control extraction sockets; fibrotic tissue surrounded by inflammatory cell infiltration was also visible.

In the alloplastic graft 1 group, at four weeks following extraction, some residual alloplastic materials remained in the extraction sockets. In addition, inflammatory cells were present, and no new bone formation was visible. At 6-week post-extraction, no residual alloplastic material was identified in the sockets, and trabecular bone formation was present in both of the peripheral regions and the central

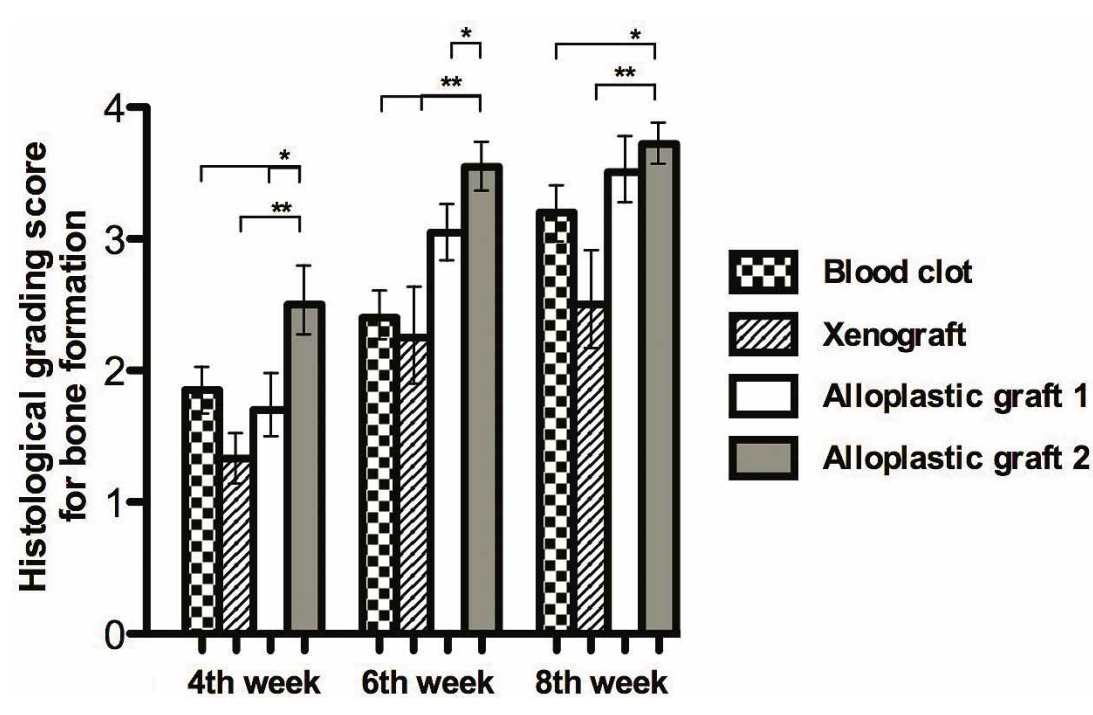

Fig. 2. Histopathological findings of various grafts used in socket healing. At 4 week postextraction, the sections exhibited significantly greater amounts of new bone formation in the sockets of the Group treated with alloplastic graft 2 than those in the alloplastic graft 1, xenograft, and control groups (blood clot). After 6 week, at least 2 or more sites of new bone or ossicle formation were visible in both alloplastic graft groups. After 4, 6, and 8 week, the sockets treated with alloplastic graft 2 received the highest qualitative scores for bone formation $(\mathrm{P}<0.05)$, followed by those treated with the alloplastic graft 1 , the control extraction sockets, and those treated with the xenograft, in the order of decreasing scores.

\footnotetext{
*= Indicate significant differences, $\mathrm{P}<0.05$ between the groups labeled, with each.

$* *=$ Indicate significant differences, $\mathrm{P}<0.01$, between the groups labeled, with each.
} 
region of the beta-tricalcium phosphate-treated sockets. Osteons and Haversian canals were visible at a higher magnification. At eight weeks post-extraction, most of the socket regions were occupied by newly formed and loose trabecular bone.

In the alloplastic graft 2 groups, at four weeks following extraction, most of the graft was degraded. Granulocyte infiltration was visible at the periphery of the graft. In approximately $50 \%$ of the sockets, trabecular bones formed between the peripheral and central regions of the sockets. Thus, the extraction sockets treated with biphasic calcium phosphate sustained more extensive new bone formation than that of the other study groups. At eight weeks post-extraction, the sockets were almost entirely filled with trabecular bone and the degree of calcification was more extensive than that observed at previous time points.

\section{DISCUSSION}

The dental alveolus is ideal for bone formation after a tooth extraction since all the relevant factors are present to maintain immobilization and graft (Becker et al., 1994). Molars were the focus of this research since the size and morphology of the sockets are quite different from those of single-rooted teeth and, therefore, the healing processes are not comparable. On the other hand, this surgical model in rabbits has offered advantages over the cost, space, storage and maintenance.

Xenografts, such as bovine bone material and alloplastic substitutes (like pure phase beta-tricalcium phosphate and biphasic calcium phosphate), encourage the apposition of new bone by osteoconduction (Norton et al., 2003). Eventually, anorganic bone allograft and hydroxyapatite become incorporated, whereas demineralized bone allograft, calcium sulphate or tricalcium phosphate are completely restituted during bone regeneration (De Coster et al., 2011).

The biomaterial-based biphasic calcium phosphate showed a lower amount of residual grafting $(\mathrm{p}<0.05)$ compared with biomaterials consisting of deproteinized bovine bone and pure phase beta-tricalcium phosphate (Pereira \& Oliva, 2014). Calixto et al. (2007) and Araújo et al. (2009) reported that placing certain type of filling particles or residual grafting produces a delay in bone repair. This delay is attributed to a foreign body reaction after implantation of the particles, which were surrounded by multinucleated cells and inflammatory tissue. In our study, there were neither pathological inflammatory phenomena nor delay in bone remodeling at any of the time points studied. Blood clot was similar. An interesting advantage of synthetic (alloplastic) bone graft substitutes are manufactured from mineral raw materials; their composition is precisely defined and availability is unlimited. There is no possibility of transmission of disease pathogens or rejection reactions. In general, patients do not have any ethical concerns when synthetic bone graft substitutes are used (Ruffieux, 2014).

In all our tested groups, bone formation begins from the side walls into the interior area, confirming that when the socket has an appropriate condition of blood supply, the type of material used in the filled can be less important than the quality of surrounding tissue (de Oliveira et al., 2014).

Numerous tissue augmentation techniques (hard and soft) have been proposed to recreate missing structures that would facilitate implant placement (Lopez et al., 2013), as well as ridge preservation approaches to minimize bone loss after tooth extraction (McAllister and Haghighat, 2007). However, the indication of specific approaches to achieve a predictable and satisfactory outcome in a given scenario remains a significant challenge in clinical practice (Bassi et al., 2013). This is suggestive of the role that individual systemic and local characteristics may play on the rate, extent, and timing of ridge resorption (Avila-Ortiz et al., 2014). In this sense, Mendoza et al., (2013) establish that bone loss caused by tooth loss is more important in the area of the first and second molar when compared with the first and second premolar.

Histomorphometric data of the present study show no differences in the heights of the buccal and lingual plates when comparing the experimental group with control. This seems to indicate that the filling used may promote bone modeling of the alveolus and prevent the long-term contraction of the marginal ridge, which is consistent with other studies in which bone fillings were used alone or combined with osseointegrated implants. A variety of factors may influence ridge resorption patterns-such as the number of neighboring teeth to be extracted, socket morphology (i.e., single- vs. multirooted teeth and socket integrity), periodontal biotype (i.e., bony buccal plate and soft tissue thickness), grafting material (Duque Netto et al., 2013), smoking status, systemic factors (e.g., uncontrolled diabetes, bone metabolic disorders), and patient compliance (Avila-Ortiz et al.).

We found that alveolar ridge preservation using bone graft is effective in limiting physiologic ridge reduction as compared with tooth extraction alone. On the other hand, although it is generally acknowledged that flap elevation has a detrimental impact in bone remodeling because of the 
interruption of the periosteal vascular supply and an increase in postsurgical local inflammation, recent preclinical evidence indicates that flap elevation does not promote alveolar bone loss (Araujo \& Lindhe, 2009; Fickl et al., 2011).

\section{CONCLUSION}

Alveolar ridge preservation via socket filling with a xenograft or an allograft can be an effective therapy to prevent physiologic bone loss after extraction of molar teeth, in both the horizontal and the vertical dimension; although, some degree bone volume loss is expected.

\section{ACKNOWLEDGEMENTS}

To "Dirección de Investigación de la Universidad de La Frontera" by support this research project DI13-0064.

CANTIN, M.; OLATE, S.; FUENTES, R. \& VÁSQUEZ, B. Conservación de la cresta alveolar por formación ósea temprana después de la extracción dentaria en conejos. Un estudio histomorfológico. Int. J. Morphol., 33(1):369-374, 2015.

RESUMEN: La pérdida de volumen cresta alveolar, es un proceso irreversible. Para evitar este evento fisiológico, que típicamente resulta en cambios anatómicos locales significativos, tanto en la dimensión horizontal y vertical, existen algunos procedimienos para reducir al mínimo la pérdida de volumen óseo que sigue típicamente a la extracción del diente. El propósito de este estudio fue evaluar si tres injertos óseos diferentes podrían promover la formación de hueso en el alveolo tras la extracción del diente para la conservación de la cresta alveolar. Los primeros molares mandibulares de conejos machos adultos fueron extraídos y los alvéolos post extracción fueron rellenados aleatoriamente con tres injertos óseos diferentes, uno de xenoinjerto y dos injertos aloplásticos, más un grupo que no recibió tratamiento (coágulo de sangre). Los alvéolos post extracción en los conejos seleccionados de cada grupo fueron evaluados a las 4, 6, o 8 semanas post-extracción. Los resultados indicaron que los alvéolos tratados con injerto aloplástico mostraron formación de hueso lamelar $(6,5 \%)$ ya a las 4 semanas post extracción. Por otra parte, el grado de formación de hueso nuevo fue significativamente mayor $(\mathrm{P}<0,05)$ en los alvéolos tratados con fosfato de calcio bifásico en 8 semanas post-extracción que en los otros grupos de estudio. Demostramos que el modelo animal propuesto es útil para evaluar la formación de hueso después de la extracción del diente, y la conservación de la cresta alveolar es factible. La nueva formación de hueso y la preservación del reborde alveolar con injerto óseo después de la extracción de los dientes molares, podrían mantener un volumen de hueso suficiente para colocar un implante en una posición ideal para la posterior restauración, sin la necesidad de procedimientos de quirúrgicos anexos.

PALABRAS CLAVE: Alveolo dentario; Injerto óseo; Pérdida de hueso alveolar; Preservación de rebordes alveolares.

\section{REFERENCES}

Araújo, M. G. \& Lindhe, J. Ridge alterations following tooth extraction with and without flap elevation: an experimental study in the dog. Clin. Oral Implants Res., 20(6):545-9, 2009.

Araújo, M.; Linder, E. \& Lindhe, J. Effect of a xenograft on early bone formation in extraction sockets: an experimental study in dog. Clin. Oral Implants Res., 20(1):1-6, 2009.

Artzi, Z. \& Nemcovsky, C. E. The application of deproteinized bovine bone mineral for ridge preservation prior to implantation. Clinical and histological observations in a case report. J. Periodontol., 69(9):1062-7, 1998.

Avila-Ortiz, G.; Elangovan, S.; Kramer, K. W. O.; Blanchette, D. \& Dawson, D. V. Effect of alveolar ridge preservation after tooth extraction: a systematic review and meta-analysis. $J$. Dent. Res. 93(10):950-8, 2014.

Bassi, A. P. F.; Vieira, R. A.; Matsumoto, M. A.; Steckelberg, I. M.; Ramalho-Ferreira, G. \& Faverani, L. P. The Fresh Frozen Bone Allograft (FFBA) to Reconstruct the Atrophic Maxilla: Evaluation of the Clinical and Histological Viability at Six and Nine Months in the MaxillarySinus. Int. J. Odontostomat., 7(2):305-13, 2013.

Becker, W.; Becker, B. E. \& Caffesse, R. A comparison of demineralized freezer-dried bone and altologous bone to induce bone formation in human extraction sokets. J. Peridontol., 65:1028-33, 1994

Boyan, B. D.; Ranly, D. M.; McMillan, J.; Sunwoo, M.; Roche, K. \& Schwartz, Z. Osteoinductive ability of human allograft formulations. J. Periodontol., 77(9):1555-63, 2006.

Calixto, R. F.; Teófilo, J. M.; Brentegani, L. G. \& Lamano-Carvalho, T. L. Grafting of tooth extraction socket with inorganic bovine bone or bioactive glass particles: comparative histometric study in rats. Implant Dent., 16(3):260-9, 2007.

Darby, I.; Chen, S. T. \& Buser, D. Ridge preservation techniques for implant therapy. Int. J. Oral Maxillofac. Implants, 24(Suppl.):260-71, 2009.

De Coster, P.; Browaeys, H. \& De Bruyn, H. Healing of extraction sockets filled with BoneCeramic $\AA$ prior to implant placement: preliminary histological findings. Clin. Implant Dent. Relat. Res., 13(1):34-45, 2011. 
de Oliveira, M.; Olate, S.; Pozzer, L.; Vásquez, B.; Cantín, M. \& Albergaría-Barbosa, J. R. Bone Repair Using Calcium Sulfate in Bone Defects of Rabbit Tibiae. Int. J. Morphol., 32(4):14726, 2014.

Duque Netto, H.; Olate, S.; Klüppel, L.; Miranda, C. M. G. A.; Salgado, I. O.; Vásquez, B. \& Albergaria-Barbosa, J. Bone Regeneration in Critical Defect Treated with Bovine Inorganic Bone Matrix with two Different Carriers. Int. J. Morphol., 31(2):367-72, 2013.

Fickl, S.; Kebschull, M.; Schupbach, P.; Zuhr, O.; Schlagenhauf, U. \& Hürzeler, M. B. Bone loss after full-thickness and partialthickness flap elevation. J. Clin. Periodontol., 38(2):157-62, 2011.

Gerritsen, A. E.; Allen, P. F.; Witter, D. J.; Bronkhorst, E. M. \& Creugers, N. H. Tooth loss and oral health-related quality of life: a systematic review and meta-analysis. Health Qual. Life Outcomes, 8:126, 2010.

Lopez, M. A.; Olate, S.; Lanata-Flores, A.; Pozzer, L.; CavalieriPereira, L.; Cantín, M.; Vásquez, B. \& de Albergaria-Barbosa, J. New bone formation in a bone defect associated to dental implant using absorbable or non-absorbable membrane in a dog model. Int. J. Clin. Exp. Pathol., 6(11):2292-9, 2013.

Manso, J. E.; Mourão, C. F.; Pinheiro, F. A.; Ferreira, M. L.; Silva, P. C. \& Schanaider, A. Molars extraction for bone graft study in rabbits. Acta Cir. Bras., 26(Suppl. 2):66-9, 2011.

Mendoza, G.; Morales, P.; Reyes, F.; Navarro, P.; Garay, I. \& Olate, S. The Alveolar Bone High in Posterior Area of Maxilla and the Relation with Tooth Loss. Int. J. Morphol., 31(3):822-5, 2013.

Olate, S.; Duque Netto, H.; Klüppel, L. E.; Vásquez, B.; Miranda, C. M. G. A. \& del Sol, M. Comparison of Bone Graft Healing Between Autogenous Bone, Blood Clot and Anorganic Bovine Bone Matrix. Radiographic and Histological Analyses. Int. J. Morphol., 31(4):1257-62, 2013.

Pereira, G. A. \& Oliva, M. P. Hydroxyapatite Effectiveness in Healing of Bone Grafts and Dental Implants: A Systematic Review of the Literature. Int. J. Odontostomat., 8(3):425-32, 2014.

Ruffieux, K. A new syringe-delivered, moldable, alloplastic bone graft substitute. Compend. Contin. Educ. Dent., 35(4 Suppl):810, 2014.

Schropp, L.; Wenzel, A.; Kostopoulos, L. \& Karring, T. Bone healing and soft tissue contour changes following single-tooth extraction: a clinical and radiographic 12-month prospective study. Int. J. Periodontics Restorative Dent., 23(4):313-23, 2003.

Seibert, J. S. \& Salama, H. Alveolar ridge preservation and reconstruction. Periodontol. 2000, 11:69-84, 1996.
Van der Weijden, F.; Dell'Acqua, F. \& Slot, D. E. Alveolar bone dimensional changes of post-extraction sockets in humans: a systematic review. J. Clin. Periodontol., 36(12):1048-58, 2009.

\author{
Correspondence to: \\ Mario Cantín \\ Faculty of Dentistry \\ Universidad de La Frontera \\ Manuel Montt 112 \\ Temuco \\ CHILE
}

Email: mario.cantin@ufrontera.cl

Received : 09-08-2014

Accepted : 21-12-2014 